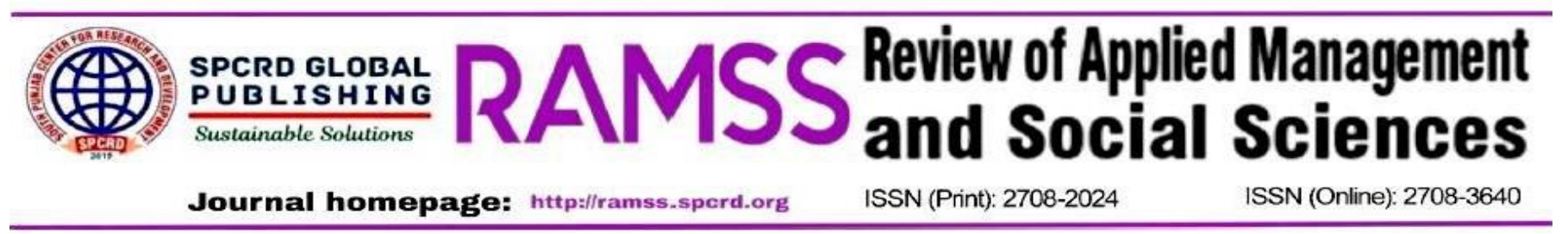

\title{
Educating Students With Hearing Impairment During Covid-19 Pandemic : A Case of Inclusive and Special Schools
}

\author{
${ }^{a}$ Samina Ashraf, ${ }^{b}$ Musarrat Jahan, ${ }^{\mathrm{c}}$ Muhammad Saad \\ ${ }^{a}$ Assistant Professor, Institute of Special education, University of the Punjab, Lahore, Pakistan. \\ Email: samina.dse@pu.edu.pk \\ ${ }^{\mathrm{b}}$ Assistant Professor, Department of Special Education, The Islamia University of Bahawalpur, Pakistan. \\ Email: musarrat,jahan@iub,edu,pk \\ c Associate Professor, Mental Health and Counseling's Ain- Shams University. Cairo. \\ Email: mohamed_osman1@edu.asu.edu.eg
}

\begin{tabular}{l}
\hline ARTICLE DETAILS \\
\hline History: \\
Accepted 22 October 2021 \\
Available Online December 2021 \\
\hline Keywords: \\
Hearing Impairment, Pandemic, \\
Education, Special Schools, \\
Inclusive School
\end{tabular}

JEL Classification:

$P_{36, I 21}$

DOI: $10.47067 /$ ramss.v4i4.183

\begin{abstract}
Observation of protocols during the COVID-19 pandemic is difficult for students with special needs particularly for students with hearing impairment (SWHI). The challenges of educating students with hearing impairment have increased after the adoption of the online education system. The purpose behind this study was to highlight the steps taken for the continuation of education in the inclusive and special schools of Punjab during a pandemic. A mixed-method approach was used to conduct this study. Two different groups of the population were taken from 9 divisions of Punjab to derive a suitable sample of this study; teachers of students with hearing impairment (SWHI) and executive members of government related to both special and inclusive schools in Punjab. The teachers from both settings were selected using random sampling. The in-depth interviews of the executive members dealing with special and inclusive schools in Punjab were conducted. The tool of the research was an interview protocol and a structured questionnaire. Data were analyzed by applying both qualitative and quantitative methods. This research has highlighted rare practices of online teaching, lack of technological resources, teachers' and students' lack of competency in online teaching, both in the special inclusive schools of the Punjab. A significant difference $(p=.000 \leq .05)$ was found between the special and inclusive schools' efforts made for the continuation of education during a pandemic.
\end{abstract}

(C) 2021 The authors. Published by SPCRD Global Publishing. This is an open-access article under the Creative Commons Attribution-

NonCommercial 4.0

Corresponding author's email address: samina.dse@pu.edu.pk 


\section{Introduction}

The virus named corona virus (COVID-19) has put the world in crisis including Pakistan (WHO, 2020).Pakistan including the majority of the countries has announced a condition of emergency to prevent the further spread of the epidemic. The government of Pakistan had to take strong decisions to control this widespread virus. The establishment of the national command and operation center (NCOC) is one of the major steps taken to deal with this epidemic. Strict lockdowns to control the movements and keep social distancing steered the closure of educational institutionsall over the country including Punjab. The Ministry of education has decided to suspend all face-to-face educational activities and shift to the online or another digital system. The closure of schools, colleges, and universities to switch traditional school-based learningto online learning has created academic discontinuity, impacted the overall quality of education of regular and special students.

The education of students with hearing impairment is offered in both the segregated and inclusive settings in Punjab.The students with hearing impairment (SWHI) have been directly affected by the learning constraints both in inclusive and segregated schools. Pupils with hearing impairment were unable to pursue their education due to school closure. However, the ministry of the government of Punjab has taken rapid actions after the first wave of COVID-19 to save the educational loss of around 50 million children in Pakistan and 12 million regular school-aged students in Punjab. The government has decided to launch a T.V.channel, awebsite, and a mobile application. The content for school-aged children was available on T.V., the web, smartphones, and the internet. The Punjab information technology (PITB) board provided the content of science and math in animated form. The PITB also helps to create a mobile app and a YouTube channel for online availability of content. Similarly, the Punjab government special education department introduced the smart curriculum, special web for students with special needs including hearing impairment. The private sectors have introduced mobile apps and YouTube channels on their own for children with hearing impairment. In addition to online learning or video-based distance education, the use of assignment methods in soft form, preparation of home assignments, e-mail of content material have also been used rarely during lockdown (Kapasia, et. al., 2020).

Both school systems have been putting great efforts to educate the special students of Punjab province since the first wave of COVID-19. Perhaps,international research studies have shown that in a pandemic, the launching of emergency distance teaching without a proper system of learning, has some shortcomings. It lacks many essential elements required for effective online teachings like internet speed, suitable pedagogy, teachers training, students' competency, online communication synchronization, online assessment, availability of sign language interpreters, and feedback sources. This situation has raised queries in the minds of researchers. This studyis aimed to explore this global scenario in the context of our local special and inclusive schools and to explore the indigenous challenges faced by our teachers during a pandemic.

\section{Literature Review}

The World Health Organization declared a pandemic on March 11, 2020, as till March 20 more than 245,972 persons and around 160 countries were affected by COVID-19.

The current pandemic has generated great trouble and interruption of education systems worldwide, affected approximately 1.6 billion students in more than 200 countries. Termination of teaching and learning activities in schools, colleges, and other learning institutions has wedged around $94 \%$ of the students globally. This has extensively changed all features of our life. The 
policies launched by the government to control this epidemic i.e., distancing in the public places and limitations in the movement haveconsiderablydistraughtusual teaching and learning procedures. The closure and reopening of academic institutions with standard operating procedures have created a challenge for the schools of students with disabilities including hearing impairment (Wolfe, et.al.,2020).

The virus has affected the world and instigated many restrictions including the closure of school across Pakistan. Since March 2020, the country has passed from three waves successfully, recently the fourth wave has to reach its peak. This repeated emergency has let the suspension of all academic activities and forced school, colleges, and universities officials to shift traditional instruction to the internet. Prominently after the second wave both the regular and special education schools have faced a daunting challenge to switch their instruction to an online system in a real manner (Young \& Donovan, 2020). During the first wave of COVID-19, the federal government has initiated "Teleschools" to continue the teaching and learning activities in a pandemic. The government of Punjab started "TaleemGher" to broadcast educational programs across the country (Zacharia,2020). No doubt, this new situation has paved the new way for introducing digital learning. But, the system was having some major flaws in it concerning students with special needs.

Almost all of the schools have discontinued face-to-face teachings as ordered by the government. A paradigm transferal in the delivery of quality education has been emerged in this pandemic, from traditional education tovarious online platforms. Online learning has brought many challenges for both the teachers and the students. There is no one-size-fits-all pedagogy for students with hearing impairment due to their diverse needs. The SWHI has different levels, grades, and age groups that require adaptations in online teaching (Hashim, Tasir\&Mohamad, 2013).

Online education has many complexities while implemented in Pakistan. The use of suitable and relevant pedagogy for online education is one of the major challenges among them. It requires the proficiency and understanding of information and communications technology of both the teachers and the students. The most frequently used online platforms in Pakistan for online teaching and learning were Microsoft Teams, Zoom, and Google Classroom. Through these platforms, the teachers keep the learning process ongoing in pandemics (Pokhrel, \&Chhetri,2021).

These online platforms provided facilities for chat, video meetings, and file storage. The teacher can share a variety of content like Word, PDF files, audio, and videos. Moreover, teachers have launched theirown YouTube channels to educate students with hearing impairment in a pandemic. Through these various methods, the education of SWHI has been taking place in the schools of Punjab(Al-Osaimi, AlFedaghi, \&Alsumait, 2009).

Students with hearing impairment, usually possess the same level of intelligence as the students with normal hearing in terms of studying. They are categorized broadly into two major groups; deaf and hard of hearing. Deaf and hard-of-hearing students use specific technologies to aid their learning in routine classroom activities (Alsadoon\&Turkestani, 2020).In a pandemic, the use of video streaming, chat rooms, video conference, text adaptation, and interactive and social tools are required to make online learning fruitful for them. In video streaming, the knowledge is transferred through the use of sign language for hearing impaired students. To ensure the quality of the sign language video presented to the SWHI, the presentation of clear and understandable signs, the resolution, frame format, file format, and frame bit rate must be taken into consideration. 
The use of integrated communication (consisting of chat and video conference) facilitates the SWHI to communicate and involve in the collective task during class (Drigas\&Kouremenos, 2005). It allows SWHI, clarify their concept and discuss their thoughts (Khwaldeh et al., 2007). Thus the interactive and effective interface of the e-learning situation could improve the learning and performance of the SWHI (Al-Osaimi et. al., 2009). Bueno et al. (2007) has stressed the use of a knowledge database for the learning of the language of SWHI while using e-learning resources.

Teaching students with hearing impairment in pandemic has many challenges for school staff, parents, and learners. For instance, the adaptation in online platforms, educational tools required for online education, and frequent glitches of internet facilities appeared major challenges both for the students and teachers. In addition to this, the availability of proper school policy of online education, accessibility, affordability of digital devices, flexibility in pedagogy, and quality of assessment procedures are some other problems experienced during the pandemic. In Pakistan, like many other developing countries, students from low financial status experienced these challenges more as compared to other students (Sari, \&Nayır, 2020).

Due to the issue of accessibility of digital resources and affordability of online learning, the overall quality of education for learners with hearing problems has decreased (Sintema, 2020). In addition to academic challenges, school closure has raised many social and psychological repercussions on the life of SWHI. In the light of the above discussion, this study was conducted with the purpose to explore the indigenous situation of education for the students with hearing impairment in pandemic and the nature of challenges our teachers are facing during this pandemic.

\section{Research Objectives}

This paper aims to achieve the following objectives.

1. Highlight the role of the special and inclusive education institution for teaching students with hearing impairment during a pandemic.

2. Explore the efforts made by the Government to support the online teaching and learning process for students with hearing impairment during a pandemic.

3. Highlight the challenges faced by the teachers while teaching students with hearing impairment during a pandemic.

4. Explore the difference of actions taken by the special and inclusive schools during a pandemic.

5. Find out the differences between the views of teachers teaching in different divisions of Punjab?

\section{Implications of the study}

This study will have practical and theoretical significance on its successful completion. The policymakers can upgrade their online system of education by taking guidance from the findings of this study. The study may raise the quality of education for students with hearing impairment during the lockdown in the future. The study will raise awareness among community members, parents and other stakeholders regarding the continuation of the academic process during the unusual scenarios in the future as the pandemic situation is still existing. The study may have a positive impact on the education of students with others impairments too who are studying in regular schools. This study sensitizes the executive members of public sector inclusive schools about the needs of special students in general. 


\section{Methodology}

The study was conducted through Qual and Quan method (mixed-method). The population of the study was comprised of two distinctive groups. The first group was comprised of the executive member from the Punjab government dealing with special and inclusive schools. The second group of the population was comprised of teachers of students with hearing impairment, teaching in the special and inclusive schools of Punjab. The sample for quantitative data was selected through random sampling technique which was teachers of the students with hearing impairment.A total number of 87 teachers (SSET and JSET) were selected from special schools, whereas 18 teachers were taken from inclusive schools. Four (4) executive members were taken as a sample for qualitative data. Two different types of instruments were used to collect the data; a structured questionnaire and an interview protocol. Both of the instruments were piloted. The reliability of the structured questionnaire was measured that was .80. The content validity was estimated by taking the opinion of 3 experts from the field of special education.

Table No.1: Demographics of the sample $\quad \mathrm{N}=105$

\begin{tabular}{|c|c|c|c|c|c|c|c|}
\hline \multicolumn{2}{|l|}{ Gender } & \multicolumn{2}{|c|}{ Age(years) } & \multicolumn{2}{|l|}{ Education } & \multirow{2}{*}{$\begin{array}{l}\text { Experience } \\
1-5 \text { years }\end{array}$} & \multirow{2}{*}{$\begin{array}{l}\text { Percentage } \\
77.1 \%\end{array}$} \\
\hline Male & Female & $21-25$ & $27.6 \%$ & B.Ed/M.Ed & $3.8 \%$ & & \\
\hline $24.8 \%$ & $75.2 \%$ & $26-30$ & $55.2 \%$ & M.A & $68.6 \%$ & $6-10$ & $18.0 \%$ \\
\hline Post & & $31-35$ & $14 \cdot 3 \%$ & M. Phil & $26.6 \%$ & $11-15$ & $2.0 \%$ \\
\hline $\begin{array}{l}\text { JSET } \\
57.1 \%\end{array}$ & $\begin{array}{l}\text { SSET } \\
42.9 \%\end{array}$ & $\begin{array}{l}36 \\
\text { above }\end{array}$ & $2.9 \%$ & Ph. D & $1 \%$ & 16 and above & $2.9 \%$ \\
\hline Total & $100 \%$ & Total & $100 \%$ & Total & $100 \%$ & Total & $100 \%$ \\
\hline
\end{tabular}

Data were collected in two phases. Firstly the data was gathered from the teachers of inclusive and special schools through questionnaires. Secondly,the interviews of the executive members of regular (1) and special educationdepartments (3)have been conducted. The interviews were also recorded and latterly transcribed for the data analysis. Each of the interviews was conducted for the duration of 20 to 30 minutes. 


\section{Results}

The collected data were subjected to both quantitative and qualitative analysis. The responses of the teachers have presented in the following table.

Table No.2: Frequency and percentages of teachers' responses on the efforts taken to continue the teaching and learning process in Covid-19 pandemic

\begin{tabular}{|c|c|c|c|c|c|}
\hline \multirow[b]{2}{*}{ Sr.No. } & \multirow[b]{2}{*}{ Statements } & \multicolumn{2}{|c|}{ Segregated $N=87$} & \multicolumn{2}{|c|}{ Inclusive $\mathrm{N}=18$} \\
\hline & & Yes & No & Yes & No \\
\hline 1 & $\begin{array}{l}\text { The smart syllabus was offered to SWHI } \\
\text { during a pandemic. }\end{array}$ & $5.8 \%$ & $94.2 \%$ & $97.6 \%$ & $2.4 \%$ \\
\hline 2 & $\begin{array}{l}\text { The captions and transcripts were used } \\
\text { during the lecture. }\end{array}$ & o\% & $100 \%$ & $10 \%$ & $90 \%$ \\
\hline 3 & $\begin{array}{l}\text { The Government provides support to } \\
\text { organize online classes during the } \\
\text { pandemic. }\end{array}$ & $15 \cdot 9 \%$ & $84.1 \%$ & $40 \%$ & $60 \%$ \\
\hline 4 & $\begin{array}{l}\text { The parents were provided training to } \\
\text { facilitate the education of their SWHI at } \\
\text { home. }\end{array}$ & $1.1 \%$ & $98.9 \%$ & $83.8 \%$ & $16.2 \%$ \\
\hline 5 & $\begin{array}{l}\text { The online helpline was introduced for the } \\
\text { parents to take help for home education. }\end{array}$ & $2.6 \%$ & $97.4 \%$ & $20.0 \%$ & $80.0 \%$ \\
\hline 6 & $\begin{array}{l}\text { The school has a system to upload teaching } \\
\text { material to assist the parents during a } \\
\text { pandemic. }\end{array}$ & $10.1 \%$ & $89.9 \%$ & $98.9 \%$ & $1.1 \%$ \\
\hline 7 & $\begin{array}{l}\text { The school has devised a system for } \\
\text { teachers' training to build their } \\
\text { competency required for online teaching? }\end{array}$ & O\% & $100 \%$ & $33.7 \%$ & $66.3 \%$ \\
\hline 8 & $\begin{array}{l}\text { The school has designed a foolproof } \\
\text { mechanism for online assessment during a } \\
\text { pandemic? }\end{array}$ & $5.9 \%$ & $94.1 \%$ & $33.7 \%$ & $66.3 \%$ \\
\hline 9 & $\begin{array}{l}\text { The teachers have the facility to teach } \\
\text { through various platforms of social media? }\end{array}$ & $11.7 \%$ & $88.3 \%$ & $13.8 \%$ & $86.2 \%$ \\
\hline 10 & $\begin{array}{l}\text { The teachers allocate small assignments } \\
\text { through WhatsApp messages? }\end{array}$ & $13.8 \%$ & $86.2 \%$ & $5 \cdot 9 \%$ & $94.1 \%$ \\
\hline
\end{tabular}


Review of Applied Management and Social Sciences (RAMSS) Vol. 4, (4) 2021, 783- 793

\begin{tabular}{|c|c|c|c|c|c|}
\hline 11 & $\begin{array}{l}\text { The school has provided the facility of } \\
\text { smart classrooms. }\end{array}$ & $01 \%$ & $99 \%$ & $10 \%$ & $90 \%$ \\
\hline 12 & $\begin{array}{l}\text { The students are being supported by sign } \\
\text { language interpreters. }\end{array}$ & O\% & $100 \%$ & $1 \%$ & $99 \%$ \\
\hline 13 & $\begin{array}{l}\text { Teachers use sign language along with the } \\
\text { verbal method. }\end{array}$ & $100 \%$ & $\mathrm{O} \%$ & $90 \%$ & $10 \%$ \\
\hline 14 & $\begin{array}{l}\text { The lectures are being uploaded on daily } \\
\text { basis for SWHI. }\end{array}$ & $97.4 \%$ & $2.6 \%$ & $98.0 \%$ & $2.0 \%$ \\
\hline 15 & $\begin{array}{l}\text { The school provides technical help in } \\
\text { uploading the teaching material. }\end{array}$ & $2.8 \%$ & $97.2 \%$ & $70 \%$ & $30 \%$ \\
\hline 16 & $\begin{array}{l}\text { Teachers upload class notes through a web } \\
\text { portal. }\end{array}$ & $14.5 \%$ & $85.5 \%$ & $88.1 \%$ & $11.9 \%$ \\
\hline 17 & $\begin{array}{l}\text { The school provides financial support to } \\
\text { purchase online resources. }\end{array}$ & $\mathrm{O} \%$ & $100 \%$ & $\mathrm{O} \%$ & $100 \%$ \\
\hline 18 & $\begin{array}{l}\text { The teachers send material through e-mail } \\
\text { to parents }\end{array}$ & $4.1 \%$ & $95.9 \%$ & $22.1 \%$ & $77.9 \%$ \\
\hline 19 & $\begin{array}{l}\text { Teachers send material to the students } \\
\text { through regular mail }\end{array}$ & O\% & $100 \%$ & O\% & $100 \%$ \\
\hline 21 & $\begin{array}{l}\text { The teachers ensure the use of hearing } \\
\text { aids by the SWHI for access to online } \\
\text { lectures. }\end{array}$ & $22.3 \%$ & $77 \cdot 7 \%$ & $77 \cdot 3 \%$ & $22.7 \%$ \\
\hline 22 & $\begin{array}{l}\text { The school has a system of knowledge } \\
\text { database according to the needs of SWHI }\end{array}$ & $9 \%$ & $91 \%$ & $20.2 \%$ & $79.8 \%$ \\
\hline \multicolumn{6}{|c|}{ Challenges } \\
\hline 23 & $\begin{array}{l}\text { Teaching in a pandemic is a challenging } \\
\text { task. }\end{array}$ & $81.9 \%$ & $18.1 \%$ & $100 \%$ & O\% \\
\hline 24 & $\begin{array}{l}\text { Training of teachers and students is a } \\
\text { great challenge to arrange online classes }\end{array}$ & $100 \%$ & O\% & $100 \%$ & O\% \\
\hline 25 & $\begin{array}{l}\text { The availability of technological devices } \\
\text { for proper access to online teaching \& } \\
\text { learning is a great challenge. }\end{array}$ & $95.1 \%$ & $4.9 \%$ & $100 \%$ & $\mathrm{O} \%$ \\
\hline 26 & $\begin{array}{l}\text { Parents' financial problems are a great } \\
\text { challenge for access to digital resources. }\end{array}$ & $95.1 \%$ & $4.9 \%$ & $98.1 \%$ & $1.9 \%$ \\
\hline
\end{tabular}


Review of Applied Management and Social Sciences (RAMSS) Vol. 4, (4) 2021, 783- 793

\begin{tabular}{|c|c|c|c|c|c|}
\hline 27 & $\begin{array}{l}\text { Lack of proper infrastructure for E- } \\
\text { learning is a challenge to pursue the T\&L } \\
\text { process in a pandemic. }\end{array}$ & $100 \%$ & O\% & $100 \%$ & O\% \\
\hline 28 & $\begin{array}{l}\text { Uninterrupted internet access is a great } \\
\text { challenge to continue the } T \& L \text { process in a } \\
\text { pandemic. }\end{array}$ & $94.7 \%$ & $5 \cdot 3 \%$ & $100 \%$ & O\% \\
\hline 29 & $\begin{array}{l}\text { The lack of proper policy to support the } \\
\text { T\&L procedures in a pandemic is a great } \\
\text { challenge. }\end{array}$ & $98.8 \%$ & $1.2 \%$ & $88.5 \%$ & $11.5 \%$ \\
\hline
\end{tabular}

Find out the difference between the availability of teaching \& learning services in different divisions of Punjab during a pandemic.

Table II: Analysis of variance (ANOVA) was performed on teachers' views on teaching and learning services during the pandemic indifferent districts.

\begin{tabular}{|l|l|l|l|l|l|}
\hline Mean & Square's & Df & Mean Square & F & Sig. \\
\hline Between Groups & 260.057 & 24 & 10.836 & 1.483 & .109 \\
\hline Within Groups & 452.932 & 62 & 7.305 & & \\
\hline Total & 712.989 & 86 & & & \\
\hline
\end{tabular}

The ANOVA tables show no statistically significant difference in the views of teachers regarding the teaching and learning services available in pandemic and challenges faced by the teachers in online teaching $(1.483, \mathrm{sig}=.109)$. It shows that the situation is similar across the schools of different districts.

Table III: Independent sample t-test was performed to see the difference in teaching \& learning during the pandemic in special and inclusive schools.

\begin{tabular}{|l|l|l|l|l|}
\hline Type of school & N & Mean & Std. Deviation & Sig \\
\hline Special & 87 & 38.78 & 6.979 & .000 \\
\hline Inclusive & 18 & 51.11 & 6.659 & \\
\hline
\end{tabular}


The above table shows astatistically significant difference between the views of teachers on teaching and learning services during pandemics and challenges faced by them in special and inclusive settings $\left(\mathrm{XG}_{1}=38.78, \mathrm{XG}_{2}=51.11\right.$, sig $\left.=.000 \leq .05\right)$. The statistically significant difference is assumed between the teachers of inclusive and special settings on the efforts made by their schools to continue education in a pandemic.

\subsection{Results derived from interviews}

The qualitative segment of this study was conceded out via in-depth interviews of executive members responsible for school policy during a pandemic. The data has established 4 major themes.

\section{Policy Execution}

The executive members of the special education department have expressed the need for resources for the execution ofonline education policy.Proper digital infrastructure is required for quality online education which is not possible without financial resources.

\section{Digitalcompetence}

The theme of digital competence has appeared as vital competence of both the teachers and learners to be successful during a pandemic. It is an emerging competence to meet the challenges of the digital world particularly when the education system has completely switched to online learning systems.Lack of competence in digital technologyhas created barriers in teaching and learning during a pandemic.

\section{Ensuring access}

The theme access is a multiplex theme. The respondents have discussed factors related to access. For instance, the affordability of advanced devices including mobiles and computers,lack of availability of learning material in pictorial/video forms, reduced students teacher interaction lack of internet facilities, availability of visual classrooms (VCs) are major barriers to access narrated by executive members. Less use of digital hearing aids by the learners due to affordability has also reduced access to online learning.

\section{Support system}

All 4 interviewees expressed the need for a proper support system. This theme has discussed two tires of support systems; from the government to the schools' management, from schools to the students and their parents.

\section{Discussion}

This study has explored the status of teaching and learning in the inclusive/regular and special schools across Punjab during a pandemic. Education of students with hearing impairment has never remained an easy task due to limitations in hearing. Even under the best conditions, their academic needs are often unmet. The study has highlighted that the challenges of education of hearing-impaired students have increased to a greater extent due to the shift of the face-to-face education system to online and distance learning. The teachers of special schools have reported that the smart syllabus was offered to SWHI during a pandemic. The school provided technical help in uploading the teaching material and the majority of teachers used sign language along with verbal communication (Reimers, Schleicher, Saavedra \&Tuominen, 2020), lectures were uploaded on daily basis for SWHI.Some of the teachers have reported that they ensured the use of hearing aids by their SWHI for their increased access. These findings confirm with the international research study 
conducted by Wolfe, et., al. (2020). The lack of a system to guide the parents has been highlighted by the study. Parents problems has increased due to school lock down and schools need to provide a continuous system of parental counseling (Bin Nordin, Iqbal \&Bajwa, 2021).

The study highlighted major challenges as mentioned by the teachers of students with hearing impairment in inclusive and special settings, training of teachers( Sari \&Nayır, 2020), availability of technological devices for proper access to online teaching and learning (Hanjarwati\&Suprihatiningrum, 2020), parents' financial problems, lack of proper infrastructure for E-learning (Hastie, Dornan, Chen \& Smith, 2011), uninterrupted internet access (Lassoued, Alhendawi\&Bashitialshaaer,2020) and lack of proper school policy to support the teaching and learning procedures during a pandemic.

The four major themes have appeared from the in-depth interviews of executive members of the special education department. Many similarities have been identified in these themes and data gathered from the teachers' interviews. For instance, the theme policy execution, access, and need for a support system have also been highlighted by the teachers of both the inclusive and special schools of Punjab. The theme of digital competence has been highlighted by the directors. They expressed the need for digital skills and competence among teachers and learners with hearing impairment to maximize the benefits of online teaching during the COVID-19 pandemic. This competence requires getting maximum knowledge and skills of the digital world (Portillo, Garay, Tejada \& Bilbao, 2020). The theme access has highlighted the factors influencing access to learning during the COVID-19 pandemic. Access to educational activities by students with visual impairment has decreased significantly due to the disconnection of face-to-face teaching in proper settings (Alsadoon\&Turkestani, 2020).Access is impacted due to the economic crisis too as highlighted by the government officials (Mamun, \&Ullah, 2020).The majority of our students enrolled in public sector schools belong to the lower middle and poor class, cannot afford the latest technological devices. The theme support system highlighted the need for a restructuring of the existing support system of schools to addressnumerousaspects of online learning for example the digitalization of infrastructure, collaboration with students and their parents, the ability of teaching staff to meet the students' needs during online learning (Hodges, et al., 2020).

\section{Conclusion}

Though the special schools have taken steps to resume the educational activities through an online medium in the COVID-19 pandemic, still there is a long way to go ahead to have an effective online educational system. The regular schools of Punjab province should also expedite the online system of education to keep the students with hearing impairment on right track. We know that students with hearing impairment need extraordinary adaptations to get benefits from online learning activities. They correspond using sign language, body language, lip-reading, and facial expressions to express themselves in the classroom. Thus, the teachers require to conduct online classroom sessions having a visible sign language interpreter. Regular schools will have to do a lot more as the prime responsibility of education of persons with special needs now shifted to them.

\section{Recommendations}

1. The study recommends adopting the existing schools into digital schools.

2. Teachers' and students' training should be focused on the area of technology.

3. There is a need to strengthen the regular/inclusive schools to provide a quality education through alternatives mediums of education in the COVID -19 pandemic. 


\section{Limitations and delimitations of the study}

Following were the delimitations of the study

- The majority of the data were collected from the teachers through social media, online interviews, and Google forms.

- Only 4 members of executive bodies were personally interviewed by observing SOPs.

- Due to the less enrollment of hearing-impaired students in public sector inclusive schools, the majority of the data were collected from private sector inclusive schools.

\section{References}

Al-Osaimi, A., AlFedaghi, H., \&Alsumait, A. (2009). User interface requirements for e-learning program designed for deaf children. Proceedings of the first Kuwait conference on e-Services and e- Systems (p.7), ACM.

Alsadoon, E., \&Turkestani, M. (2020). Virtual Classrooms for Hearing-impaired Students during the COVID-19 Pandemic. Romanian Journal for Multidimensional Education/Revista12.

Bin Nordin, M. N., Iqbal, F., \&Bajwa, R. S. (2021). Challenges of parents in the implementation of teaching process and facilitation at home during movement control order for students with special needs with hearing impairment in Malaysia. Psychology and Education Journal, 58(2), 9188-9193.

Bueno, F. J., Fernándezdel Castillo, J. R., Garcia, S., \& Borrego, R. (2007). E-learning content adaptation for deaf students. ACM SIGCSE Bulletin , 39(3), (pp. 271-275), ACM.

Drigas, A. S., \&Kouremenos, D. (2005). An e-learning management system for the deaf people. WSEAS .Transactions on Advances in Engineering Education, 1(2), 20-24.

Hanjarwati, A., \&Suprihatiningrum, J. (2020). Is online learning accessible during COVID-19 Pandemic? Voices and Experiences of UIN SunanKalijaga Students with Disabilities. Nadwa, 14(1), 1-38.

Hashim, H., Tasir, Z., \&Mohamad, S. K. (2013). E-Learning Environment for Hearing Impaired Students. Turkish Online Journal of Educational Technology-TOJET, 12(4), 67-70.

Hayes, S. D., Flowers, J., \& Williams, S. M. (2021, January). “Constant Communication”: Rural Principals' Leadership Practices During a Global Pandemic. In Frontiers in Education (Vol. 5, p. 277). Frontiers.

Hodges, C., Moore, S., Lockee, B., Trust, T., \& Bond, A. (2020). The difference between emergency remote teaching and online learning. Educause Review, 27. https://er.educause.edu/articles/2020/3/

Kaminskienè, L., Tūtlys, V., Gedvilienè, G., \& Chu, L. Y. (2021). Coping with the pandemic and the school lockdowns: The perspective of Lithuanian school principals. Journal of Contemporary Educational Studies/SodobnaPedagogika, 72.

Kapasia, N., Paul, P., Roy, A., Saha, J., Zaveri, A., Mallick, R., \&Chouhan, P. (2020). Impact of lockdown on learning status of undergraduate and postgraduate students during COVID-19 pandemic in West Bengal, India. Children and Youth Services Review, 116, 105194.

Kerrissey, M., and Edmondson, A. (2020). What good leadership looks like during this pandemic? Harvard Business Review. Retrieved from https://hbr.org/2020/o4/what-goodleadershiplooks-like-during-this-pandemic (Accessed on 20.12. 2020).

Khwaldeh, S., Matar, N., \&Hunaiti, Z. (2007). Interactivity in deaf classroom using centralized Elearning system in Jordan. PGNet, ISBN, 1-9025.

Lassoued, Z., Alhendawi, M., \&Bashitialshaaer, R. (2020). An exploratory study of the obstacles for achieving quality in distance learning during the COVID-19 pandemic. Education Sciences, 10(9), 232. 
Mamun, M. A., \&Ullah, I. (2020). COVID-19 suicides in Pakistan, dying off not COVID-19 fear but poverty?-The forthcoming economic challenges for a developing country. Brain, behavior, and immunity, 1(87), 163.

Portillo, J., Garay, U., Tejada, E., \& Bilbao, N. (2020). Self-perception of the digital competence of educators during the COVID-19 pandemic: A cross-analysis of different educational stages. Sustainability, 12(23), 10128.

Pokhrel, S., \&Chhetri, R. (2021). A literature review on impact of COVID-19 pandemic on teaching and learning. Higher Education for the Future, 8(1), 133-141.

Reimers, F., Schleicher, A., Saavedra, J., \&Tuominen, S. (2020). Supporting the continuation of teaching and learning during the COVID-19 Pandemic. Oecd, 1(1), 1-38.

Sari, T., \&Nayir, F. (2020). Challenges in distance education during the (Covid-19) pandemic period. Qualitative Research in Education, 9(3), 328-36o.

Sintema, E. J. (2020). Effect of COVID-19 on the performance of grade 12 students: Implications for STEM education. Eurasia Journal of Mathematics, Science and Technology Education, 16(7), em1851.

Smith, C. (2020). Challenges and opportunities for teaching students with disabilities during the COVID-19 pandemic. International Journal of Multidisciplinary Perspectives in Higher Education, 5(1), 167-173.

UNESCO. (2020). COVID-19 Educational Disruption and Response. 15 April 2020, https://en.unesco.org/covid19/educationre.

Wolfe, J., Smith, J., Neumann, S., Miller, S., Schafer, E. C., Birath, A. L. \& Jones, C. (2020). Optimizing communication in schools and other settings during COVID-19. The Hearing Journal, 73(9), 40-42.

Young, J., \& Donovan, W. (2020). Shifting to Online Learning in the COVID-19 Spring. Policy Brief. Pioneer Institute for Public Policy Research.

Zacharia, S. (2020).Education continuity during the Coronavirus crisis: Pakistan teleschool and taleemgher. Global Education Innovation Initiative. World Bank Group. 